\title{
Clinicopathological Study of Non-Neoplastic and Neoplastic Lesions of Larynx
}

Chaitanya V ${ }^{1}$, Nikethan B ${ }^{* 2}$.

${ }^{1}$ Assistant Professor, Department of Otorhinolaryngology, JJM Medical College, Davangere, Karnataka, India.

${ }^{* 2}$ Assistant Professor, Department of Pathology, JJM M edical College, Davangere, Karnataka, India.

\section{ABSTRACT}

Background: The laryngeal lesions are significant because of the human communication through voice and contribution of voice to the identity of the person. Lesions of the larynx are classified into the commonly occurring non-neoplastic lesions and relatively neoplastic lesions. The aim of this study was to describe the clinical features of patients with non-neoplastic and neoplastic lesions of the larynx,and pathological findings of patients with this lesions.

Material and Methods: This prospective study was conducted in 80 patients who were diagnosed with various lesions of larynx during a period of three year. After a detailed history, general physical and systemic examination, complete nasal and paranasal examination, examination of ears, patients were subjected for examination of larynx which included external examination of larynx, indirect laryngoscopy under general anesthesia.

Results: The incidence was found to be 30-40 (36.6\%) years followed by the 51-60 (23.3\%) years. Non-neoplastic benign lesions were more common (62.5) as compared to neoplastic benign lesions (37.5\%) with preponderance in males $(80 \%)$ as compared to females $(20 \%)$. Hoarseness of voice was the commonest presenting symptoms being present in $15-30$ patients. It was observed that 15 patients (50\%) were smokers, 33.3\% were addicted to alcohol, $6.8 \%$ patients had history of both smoking and alcohol consumption, $3.3 \%$ had beetel nut chewing and $3.3 \%$ had history of tobacco chewing. Vocal polyp being the commonest type seen in $33.7 \%$ of cases followed by vocal nodule(22.5\%), epiglottic cyst(2.5\%), chronic laryngitis(1.3\%) and tubercular laryngitis(2.5\%), Papilloma(10\%) \& Squamous cell carcinoma(27.5).

Conclusion: The symptoms of laryngeal lesions can vary from mild hoarseness of voice to life threatening respiratory distress. All available methods of study should be utilized to make the diagnosis as early as possible. Early diagnosis of the lesion can lead to effective management.

KEYWORDS: Larynx , Laryngeal lesions, Clinicopathological.

Address for correspondence: Dr. Nikethan B, Assistant Professor, Department of Pathology, JJ M M edical College, Davangere, Karnataka, India. E-Mail: nikethanbathi@gmail.com

\begin{tabular}{|c|c|c|}
\hline \multicolumn{3}{|c|}{ Online Access and Article Informtaion } \\
\hline \multirow{2}{*}{$\begin{array}{c}\text { Quick Response code } \\
\text { Dol: } 10.16965 / \text { ijims.2015.136 }\end{array}$} & \multicolumn{2}{|c|}{$\begin{array}{l}\text { International Journal of Integrative Medical Sciences } \\
\text { www.imedsciences.com }\end{array}$} \\
\hline & $\begin{array}{l}\text { Received: 11-12-2015 } \\
\text { Reviewed: 11-12-2015 }\end{array}$ & $\begin{array}{l}\text { Accepted: 20-12-2015 } \\
\text { Published: 31-12-2015 }\end{array}$ \\
\hline Source of Funding: Self & \multicolumn{2}{|c|}{ Conflicts of interest: None } \\
\hline
\end{tabular}

\section{BACKGROUND}

The larynx is a major component of the upper respiratory tract and lies just anterior to the upper end of the digestive tract. It is, therefore, vulnerable to inflammation and other phenomenon which lead to the formation of various lesions of the larynx [1]. The larynx serves to protect the lower airways, facilitates respiration and plays a key role in phonation. The protective function is entirely reflexive and involuntary, whereas the respiratory and phonatory functions are initiated voluntarily but regulated involuntarily [2].

Tobacco use, alcohol consumption, and HPV16 infection are considered to be the major risk 
factors for this disease. Occupational risk factors that include exposure to asbestos have also been described although dust exposures other than asbestos have been historically understudied [3]. The larynx is divided into the supraglottic, glottis and subglottis based on anatomical location. Tumors of the larynx can be divided into benign or malignant. Laryngeal granulomas, vocal cord nodules, and vocal cord polyps are tumor-like (non-neoplastic) lesions of the larynx. Benign laryngeal tumors include a large number of lesions such as papillomas, hemangiomas, fibromas, chondromas, myxomas, and neurofibromas. About $95 \%$ of laryngeal carcinomas are typical squamous cell tumors. Rarely adenocarcinomas are seen to arise from larynx, presumably arising from mucous glands [4].

Squamous cell carcinoma is the predominant histologic type; approximately $40 \%$ of patients will have stages III or IV disease when first evaluated [5]. M ost cases of laryngeal cancer are associated with a history of tobacco and/or alcohol use, so the treatment of patients is complicated by medical comorbidity and the development of second primary cancers $[6,7]$.

The aim of this study was to describe the clinical features of patients with non-neoplastic and neoplastic lesions of the larynx and pathological findings of patients with these lesions.

\section{MATERIALS AND METHODS}

This was a prospective study conducted in Department of Otorhinolaryngology, J J M Medical College Davangere, Karnataka, India, over a period of three years from December 2012 to November 2015.A total 80 patients who were clinically diagnosed with laryngeal lesions irrespective of their age, sex, occupation, and onset or duration of symptoms were included. The clinical diagnosis of laryngeal lesions was made on the basis of clinical presentation and included hoarseness, foreign body sensation in the throat, dysphagia, pain or discomfort on swallowing, dyspnea, cough, aspiration, or the presence of a neck mass. Socioeconomic status were derived according to modified kuppuswamy's classification. Patients with oral and oropharyngeal lesions and cases with nasal and nasopharyngeal lesions were excluded.
A thorough history, clinical examination and Routine investiga-tions such as complete blood count and urine test for albumin and sugar were carried out in all the patients; sputum exami-nation for acid-fast bacilli, $X$-ray chestPA view, and X-ray soft tissue neck-AP and lateral views were done when required. Any patient with suspected lesions in the larynx was examined for direct laryngoscopy, and if needed, $70^{\circ}$ or $90^{\circ}$ endoscopic or flexible nasopharyn-golaryngoscopic evaluation was done under general anesthesia where a biopsy was taken from the lesion and sent for histopathological examination. Descriptive statistical measures like percentages and proportions were utilized to present the data. All the cases were managed by conservative or surgical management depending upon the pathology involved. Necessary investigations were performed routinely at each visit during follow-up.

\section{RESULTS}

In this study the patients' ages ranged from 1470 years. The peak incidence of laryngeal lesions occurred in the $30-40(36.6 \%)$ years followed by the $51-60(23.3 \%)$ years. Non neoplastic lesions were most common in the third decade $(30 \%)$ and minimum in the seventh decade (5\%). Among neoplastic lesions, the benign tumors were reported between ages $30-40$ years followed by malignant tumors between the ages of 41-70 years with maximum occurrence between the ages of 50-70 years. In both non neoplastic and neoplastic lesions, male patients constituted $80 \%$ of the study population. The male to female ratio was 8:2. Non neoplastic lesions were more in the middle class (66\%) whereas malignant tumours were reported more in the lower (46.6\%) and middle class (33.3\%). Non neoplastic lesions were seen equally in rural and urban areas, while neoplastic lesions were more common (73\%) in rural areas.

In our study hoarseness was the most common presenting symptom in $50-60 \%$ of all patients of non neoplastic and neoplastic lesions presented followed by vocal fatigue, foreign body sensation, cough, dysphagia, dyspnea, swelling in the neck, neck pain, weight loss, blood stained and sputum. The duration of 
Chaitanya V, Nikethan B. Clinicopathological Study of Non-Neoplastic and Neoplastic Lesions of Larynx.

Table 1: Distribution of cases according to clinical presentation and duration of symptoms.

\begin{tabular}{|c|c|c|c|c|c|c|c|}
\hline \multirow{3}{*}{$\begin{array}{l}\text { Presenting } \\
\text { symptoms }\end{array}$} & \multicolumn{2}{|c|}{ Non neoplastic } & \multicolumn{2}{|c|}{ Neoplastic } & \multirow{2}{*}{\multicolumn{3}{|c|}{ Duration of symptoms }} \\
\hline & \multirow{2}{*}{$\begin{array}{l}\text { Number of } \\
\text { cases }\end{array}$} & \multirow[b]{2}{*}{ Percentage } & \multirow{2}{*}{$\begin{array}{l}\text { Number } \\
\text { of cases }\end{array}$} & \multirow[b]{2}{*}{ Percentage } & & & \\
\hline & & & & & 1 month & 1-6 month & 1 year \\
\hline Hoarseness & 30 & 60 & 15 & 50 & 26 & 40 & 6 \\
\hline Vocal fatigue & 14 & 28 & 6 & 20 & 16 & 14 & 4 \\
\hline $\begin{array}{c}\text { Foreign body } \\
\text { sensation }\end{array}$ & 0 & 0 & 1 & 3.3 & 11 & 8 & 1 \\
\hline Dysphagia & 3 & 6 & 2 & 6.7 & 3 & 2 & 0 \\
\hline Cough & 0 & 0 & 1 & 3.3 & 6 & 3 & 1 \\
\hline Swelling in neck & 0 & 0 & 0 & 0 & 2 & 1 & 0 \\
\hline Dyspnea & 3 & 6 & 1 & 3.3 & 3 & 2 & 0 \\
\hline Neck pain & 1 & 2 & 1 & 3.3 & 2 & 1 & 0 \\
\hline Weight loss & 0 & 0 & 1 & 3.3 & 2 & 1 & 0 \\
\hline $\begin{array}{c}\text { Blood stained } \\
\text { sputum }\end{array}$ & 0 & 0 & 2 & 6.8 & 1 & 2 & 0 \\
\hline Total & 50 & 100 & 30 & 100 & & & \\
\hline
\end{tabular}

symptoms ranged from 1 month to 1 year; the mean duration of illness in months was $2.93 \pm$ 1.32 .

The patients were mostly involved in occupations demanding an excessive use of voice. 26 teachers (32.5\%) and 20 Farmer/ agriculturists (25\%), 10 housewives (12.5\%) constituted a major group of patients. Three patients were laborers doing heavy work. Other occupations commonly observed were, business (8 cases), driver (6cases) Carpenter (3cases) clerks ( 2 cases) and singers ( 2 cases).

In the study, among neoplastic lesions, $50 \%$ patients had history of tobacco smoking in the form of cigarette/ beedi, followed by $33.3 \%$ were addicted to alcohol, $6.8 \%$ patients had history of both smoking and alcohol consumption, 3.3\% had beetel nut chewing and 3.3\% had history of
Table 2: Distribution cases according to risk factors.

\begin{tabular}{|c|c|c|c|c|}
\hline \multirow{2}{*}{ Risk factors } & \multicolumn{2}{|c|}{ Non neoplastic } & \multicolumn{2}{c|}{ Neoplastic } \\
\cline { 2 - 5 } & $\begin{array}{c}\text { Number } \\
\text { of cases }\end{array}$ & Percentage & $\begin{array}{c}\text { Number } \\
\text { of cases }\end{array}$ & Percentage \\
\hline Smoking Cigarette & 10 & 20 & 15 & 50 \\
\hline Alcohol & 6 & 12 & 10 & 33.3 \\
\hline Alcohol +Smoking & 5 & 10 & 2 & 6.8 \\
\hline Pan/ beetel nut & 3 & 6 & 1 & 3.3 \\
\hline Tobacco chewing & 5 & 10 & 1 & 3.3 \\
\hline Vocal abuse & 17 & 34 & 0 & 0 \\
\hline $\begin{array}{c}\text { Poor orodental } \\
\text { hygiene }\end{array}$ & 3 & 6 & 1 & 3.3 \\
\hline $\begin{array}{c}\text { Occupational risk } \\
\text { factors }\end{array}$ & 1 & 2 & 0 & 0 \\
\hline Total & 50 & 100 & 30 & 100 \\
\hline
\end{tabular}

tobacco chewing. Among non neoplastic lesions, majority of the patients i.e. $34 \%$ had history of vocal abuse followed by $20 \%$ smoking and $10 \%$ were alcoholics.

Table 3: Distribution of various non neoplastic and neoplastic lesions of larynx.

\begin{tabular}{|c|c|c|c|c|c|c|c|c|}
\hline \multirow{2}{*}{\multicolumn{3}{|c|}{ Non neoplastic }} & \multicolumn{6}{|c|}{ Neoplastic } \\
\hline & & & \multicolumn{3}{|c|}{ Benign tumors } & \multicolumn{3}{|c|}{ Malignant tumors } \\
\hline Type of lesion & $\begin{array}{l}\text { No of } \\
\text { cases }\end{array}$ & Percentage & $\begin{array}{c}\text { Type of } \\
\text { lesion }\end{array}$ & Number & Percentage & $\begin{array}{l}\text { Type of } \\
\text { lesion }\end{array}$ & Number & Percentage \\
\hline Vocal polyp & 27 & 33.7 & Papilloma & 8 & 10 & $\begin{array}{c}\text { Squamous } \\
\text { cell } \\
\text { carcinoma }\end{array}$ & 22 & 27.5 \\
\hline Vocal nodule & 18 & 22.5 & & & & & & \\
\hline Epiglottic Cyst & 2 & 2.5 & & & & & & \\
\hline $\begin{array}{c}\text { Chronic } \\
\text { laryngitis }\end{array}$ & 1 & 1.3 & & & & & & \\
\hline $\begin{array}{c}\text { Tubercular } \\
\text { laryngitis }\end{array}$ & 2 & 2.5 & & & & & & \\
\hline Total & 50 & 62.5 & & 8 & 10 & & 22 & 27.5 \\
\hline
\end{tabular}


In our study 50 cases had non neoplastic lesions followed by 30 cases of neoplastic lesions which further classified in Table 3.

Non neoplastic lesions constituted about $62,5 \%$ of cases with vocal polyp being the commonest type seen in $33.7 \%$ of cases followed by vocal nodule, epiglottic cyst, chronic laryngitis and tubercular laryngitis (Table 3).

Vocal polyp was the most common lesion seen in second to third decade of life. Vocal nodule being the second most common non neoplastic lesion seen in $22.5 \%$ of cases. Neoplastic lesions constituted $37.5 \%$ of cases with $10 \%$ being benign tumours and $27.5 \%$ malignant tumours. Among the benign neoplastic lesions, squamous papilloma was the predominant type seen. Squamous cell carcinoma was the commonest malignant neoplasm comprising of $8(36.5 \%)$ cases of mild differentiated, $12(54.5 \%)$ cases of moderately differentiated and poorly differentiated in 2(09\%) patients. Squamous cell carcinoma was most commonly observed in 6th and 7 th decades. In this study, laryngeal malignancy was most commonly seen in the glottis (40.9\%), followed by the supraglottis (27.3\%) and transglottis (31.8\%).

\section{DISCUSSION}

It is important to recognize the range of non neoplastic lesions in a region and to differentiate them from neoplastic lesions because of different treatment modality and emotional burden on the patient. Functional outcome and prognosis of laryngeal lesions depend on early diagnosis. Glottic lesions produce hoarseness very early. Standard diagnosis of early laryngeal cancer is a representative biopsy or excision of the lesion.

In our study non neoplastic lesions were most common in the third decade (30\%) and minimum in the seventh decade (5\%). Among neoplastic lesions the benign tumors were reported between ages 30-40 years correlated with similar reports with Hegde $\mathrm{MC}$ et all ${ }^{1}$ and Singhal $P$ et al. [8]

Malignant tumors between the ages of 41-70 years with maximum occurrence between the ages of 50-70 years. Shirley D et al [9] stated that malignant laryngeal tumours tend to increase with age, average age of diagnosis being 66 years.

In both non neoplastic and neoplastic lesions male patients constituted $90 \%$ of the study population. The male to female ratio was 9:1 correlated with Bakshi et al. [10] in a study of 690 cases of carcinoma larynx found that 647 patients were males and 43 were females.

Non neoplastic lesions were more in the middle class (66\%) whereas malignant tumours were reported more in the lower (46.6\%) and middle class (33.3\%). Bakshi et al [10] in their study found that $60 \%$ were from the low socioeconomic status, $25 \%$ belonged to the middle class and the remaining $15 \%$ belonged to the high class.

Non neoplastic lesions were seen equally in rural and urban areas, while neoplastic lesions were more common $73 \%$ in rural areas and $27 \%$ in urban areas. Bakshi et al [10] found that $78 \%$ were rural and the remaining $22 \%$ were from urban regions, and Jaimanti [11] found $78 \%$ of cases from a rural area and $22 \%$ of cases from an urban area.

In our study hoarseness was the most common presenting symptom in $50-60 \%$ of all patients of non neoplastic and neoplastic lesions presented followed by vocal fatigue, foreign body sensation, cough, dysphagia, dyspnea, swelling in the neck, neck pain, weight loss, blood stained and sputum. Verma et al [12] reported hoarseness in $73.92 \%$, difficulty in swallowing in $59.95 \%$ and cough with expectoration in $39.04 \%$. and Bakshi et al [10] in their study found that hoarseness was the most common complaint, Other complaints were sore throat, neck nodes and haemoptysis.

In the study, among neoplastic lesions $50 \%$ patients with the history of tobacco smoking in the form of cigarette, followed by $33.3 \%$ were addicted to alcohol, $6.8 \%$ had history of both smoking and alcohol consumption, 3.3\% had beetel nut chewing, 3.3\% had history of tobacco chewing. Maier et al. [13] in a study of 164 cases found that smoking and drinking alcohol increase the dose-dependent risk of laryngeal cancer. Among non neoplastic lesions, patients presented mainly with vocal abuse (34\%) followed by $20 \%$ smoking. In the studies done 
by Ghosh et al [14] and Parikh [15] vocal abuse was observed in $72 \%$ and $56 \%$ cases, respectively.

Non neoplastic lesions constituted about $62.5 \%$ of cases with vocal polyp being the commonest type seen in $33.7 \%$ of cases as correlated to $68.3 \%$ in kambic et al [16] and $16 \%$ in chopra et al. [17]. The second most lesion noted is vocal cord nodule (22.22\%), which is the most common caus-ative factor, noted Ghosh et al. [14] In our series we had 2 cases of laryngeal tuberculosis.This is in accordance with Chopra et al [17] who had 3 cases of tuberculosis of larynx.

Neoplastic lesions constituted $37.5 \%$ of cases with $10 \%$ benign tumours and $27.5 \%$ malignant tumours. Among the benign neoplastic lesions, squamous papilloma(10\%) was the predominant type seen in the patients correlated with Shaw et al $14 \%$ [18].

Squamous cell carcinoma (22 cases) was the commonest malignant neoplasm comprising of $8(36.5 \%)$ cases of mild differentiated, $12(54.5)$ cases of moderately differentiated in $54.5 \%$, and poorly differentiated in 2 (09\%) patients. In a study Kumar et al. [19] stated that $95 \%$ of all laryngeal carcinomas are typical SCC. Jaiswal and Hoang [20] stated that out of all primary laryngeal carcinomas, $99 \%$ are SCC.

In this study laryngeal malignancy most commonly seen in the glottis (40.9\%), followed by the supraglottis $(27.3 \%)$ and transglottis (31.8\%). These results are very close to the studies Aslam M J et al [21] where glottis $56 \%$, supraglottis $36 \%$, transglottic tumours $8 \%$ and no subglottis tumour involvement seen.

\section{CONCLUSION}

The laryngeal dysfunction produces symptoms which can vary from mild hoarseness to life threatening strider. Laryngeal lesions can create lot of mental and emotional tension in the patient and the family. Early diagnosis of the lesions can lead to effective management and good recovery.

\section{REFERENCES}

[1]. Hegde MC, Kamath MP, Bhojwani K, Peter R, Babu $P R$ et al. Benign lesions of Larynx - a clinical study. Ind J Otolaryngol and Head Neck Surg 2005;57(1):35-38.
[2]. Sasaki CT (2006) Anatomy and development and physiology of the larynx. In: Goyal R, Shaker R (eds). Part 1 Oral cavity, pharynx and esophagus. Nature Publishing Group; GI M otility Online. doi:10.1038/ gimo 7

[3]. Langevin SM, McClean MD, M ichaud DS, Eliot M, Nelson HH, Kelsey KT. Occupational dust exposure and head and neck squamous cell carcinoma risk in a population-based case-control study conducted in the greater Boston area. Cancer M ed. 2013;2(6):978-86.

[4]. Sharma DK, Sohal BS, Bal MS, Aggarwal S. Clinicopathological study of 50 cases of tumors of Iarynx. Indian J Otolaryngol Head Neck Surg. 2013;65(Suppl 1):29-35.

[5]. Suen, JY; Stern, SJ. Cancer of the head and neck. In: M yers, EN; Suen, JY, editors. Cancer of the head and neck. 4th ed. Philadelphia: Saunders WB; 2003. p. 462-84.

[6]. Cumming, CW; Fredrickson, JM ; Harker, L; Krause,C]; Richardson, M A; Schuller, DA. M alignant tumors of the larynx and hypopharynx. In: Adam, GL, editor. Cummings otolaryngology head and neck surgery. $5^{\text {th }}$ ed. Chicago: Elsevier (M osby); 2010. p. 2130-75.

[7]. Hong WK, Lippmann SM, Itri LM, Karp DD, Lee JS, Byers RM, et al: Prevention of second primary tumors with isotretinoin in squamous-cell carcinoma of the Head and Neck. N Engl J Med. 1990;323(12):795-801.

[8]. Singhal $P$, Bhandari A, Chouhan $M$, Sharma MP, Sharma Set al. Benign tumours of larynx: A clinical study of 50 cases. Ind J Otolaryngol Head Neck Surg 2009,(suppl 1);26-30.

[9]. Shirley D (1997) Cartilaginous lesions of the larynx. Grand rounds archives BCM. Bobby R Alford Department of Otolaryngology: Head and Neck Surgery.

[10]. Bakshi J, Panda NK, Sharma S, Gupta AK, M ann SBS. Survival patterns in treated cases of carcinoma larynx in North India: a 10 years follow up study. Ind J Otolaryngol Head Neck Surg. 2004;56(2):99103.

[11]. Jaimanti, Panda NK, Sharma S, Gupta AK, M ann SB. Survival patterns in treated cases of carcinoma larynx in north india - a 10 years followup study. Indian J Otolaryngol Head Neck Surg. 2004;56(2):99104.

[12]. Verma M S, Panda NK, Mann S.B.S, Mehra YW. Presentation of carcinoma larynx and laryngopharynx: An analysis of 840 cases. The Journal of Otology and Laryngology. 1990; 42(2): 50-3.

[13]. Maier H, Gewelke U, Dietz A, Heller W. Risk factors of cancer of the larynx: results of the Heidelberg case-control study. Otolaryngol Head Neck Surg. 1992;107(4):577-82.

[14]. Ghosh SK, Chattopadhyay S, Bora H, M ukherjee PB. Microla-ryngoscopic study of 100 cases of hoarseness of voice. Indian J Otolaryngol Head Neck Surg 2001;53(4):270-2. 
[15]. Parikh N. Aetiology study of 100 cases of hoarseness of voice. Indian J Otolaryngol Head Neck Surg 1991;43(2):71-3.

[16]. Kambic V, et al. Vocal cord polyps: Incidence, histology and pathogenesis. J Laryngol Otol 1981;95:609-18.

[17]. Hemant Chopra, M inisha Kapoor. Study of benign glottic lesions undergoing microlaryngeal surgery. Indian J Otolaryngol Head Neck Surg 1997;49:2769

[18]. Shaw H. Tumours of Larynx In: Scott - Brown; Diseases of Ear, Nose and Throat, 4th edn edited by Ballantyne and J. Groves. London; Butterworths. 1979:421-508.
[19]. Kumar V, Abas AK, Fausto N. Robins and Cotran's pathologic basis of disease, 7th edn. Saunders, India 2004;786-787.

[20]. Jaiswal VR, Hoang M P. Primary combined squamous and small cell carcinoma of the larynx. Arch Pathol Lab Med 2004;128:1279-1281.

[21].Aslam M J, Ahmed Z, Aslam M A, Ahmed MI. Complications of total laryngectomy. PakJ M ed Sci 2006;22(1):33-7.

How to cite this article:

Chaitanya V, Nikethan B. Clinicopathological Study of Non-Neoplastic and Neoplastic Lesions of Larynx. Int J Intg Med Sci 2015;2(12):200-205. DOI: 10.16965/ijims.2015.136 